\title{
The Revolutionary Person
}

\author{
Penitence, Sacrifice, and the New Man
}

\begin{abstract}
Man will make it his purpose to master his own feelings, to raise his instincts to the heights of consciousness, to make them transparent, to extend the wires of his will into hidden recesses, and thereby to raise himself to a new plane, to create a higher social biologic type, or, if you please, a superman.

- LEON TROTSKY
\end{abstract}

This epigraph is taken from Literature and Revolution, Trotsky's famous account of how, in the classless society he thought the proletarian revolution in Russia would bring about, the arts would contribute to new forms of "self-government" in which "social construction and psycho-physical self-education will become two aspects of one and the same process" ([1924] 2005: 207). In this chapter we examine this idea-namely, that revolutionary transformations involve concerted and deliberate attempts to correlate changes at broader political and social levels (i.e., the kinds of transformations we explored in the previous chapter) with changes that go deep into the most intimate aspects of people's lives. In different ways and in different senses, we suggest, revolutions can be as much projects of radical personal transformation as they are projects for sociopolitical upheaval. Indeed, more than that, we shall see that one of the abiding characteristics of revolutions is that they connect those two scales, making political change a function of changes in people's personal comportment (and very much vice versa). The characteristics of revolution as a mode of collective political action, then, must be understood in the light of its qualities as a profoundly moral project that makes personal demands on people, operating in the most intimate ambits of their lives, indeed, in some cases, on their very souls. With revolution, as the old feminist adage had it, the personal is-deliberately, abidingly, and often in a marked and recognized way-political.

This is captured most emblematically by the programmatic way in which so many revolutionary movements and states have proclaimed as a prime goal the 
creation of, if not necessarily Trotsky's "superman," then certainly a "New Man." With deep roots in Enlightenment ideas about the malleability of human beings through education, the idea that revolutions must transform the very fabric-both moral and physical — of the people whose lives they seek so radically to transform is one that appears again and again since the time of Robespierre, who himself, according to some accounts, conceived of the Revolution as a "school," in which "knowledge would always be augmented by morality" (Schama, cited in Cheng 2009: 11). Under the influence of Marx, the "great revolutions" of the twentieth century laid much store in casting off the yoke of oppression in order also to overcome the personal forms of "alienation" that exploitation produces. Revolutionary societies would produce "New Men," as Lenin's program would have it (e.g., Lenin [1902] 2008), not only through education of the masses, but also through the example set by the revolutionary vanguard embodied by the Party, as well as new techniques and technologies of labor, structural principles of economic and urban planning, and so on. Conceived as projects of total societal transformation, revolutions have characteristically set themselves the goal of producing new kinds of citizens-people who would take the goals of revolutionary transformation to heart, subsume themselves to its collective ends, self-sacrificially as well as selfcritically shedding selfish and material motives in favor of the moral incentives of altruism and the collective good. The good of the self, then, as the good of the revolution, and vice versa.

The deeply Christian sonorities of the concept of the New Man are as telling as they are paradoxical, considering the militantly anticlerical character of so many of the revolutions with which it has been associated. To be sure, we saw in chapter 1 the frequent connection between revolutions and ritual phenomena of various kinds, noting the significance of ideas and practices or personal transformation in such contexts (e.g., in Bloch's model of transcendent orders consuming the "inner vitality" of ritual participants and thus preparing them for revolutionary action, as in Lan's account of the Zimbabwean freedom fighters). Indeed, focusing on the demands revolutions place on people puts the relationship between revolution and religious phenomena center stage, since the latter so often constitute par excellence arenas for the conformation and transformation of people's personal comportment. Morality, altruism, asceticism, self-sacrifice, even piety and zealotry are all central to forms of life that are in different contexts considered "religious" (cf. Asad 1993), while, as we shall see in the detailed examples of this chapter, they are also deeply at stake in processes of revolutionary transformation. In that sense revolution is rather like religion, with both of them reaching deep into people's personal lives, though each with its own demands and with potentially very different-and of course sometimes radically antithetical-results. In some cases, revolutions come to replace in important respects the religious phenomena against which they are pitted, taking on in their stead the task of forming people 
in particular ways. To take a striking example, while systematically eradicating the influence of the Russian Orthodox Church, as we shall be seeing, the Bolshevik revolution famously took on some of the most basic practices of Russian Orthodox devotion. For example, as will be discussed in more detail in chapter 6 , the images of Lenin and Stalin that proliferated in both public and domestic spaces after 1917 were positioned and treated in a manner similar to consecrated Orthodox icons. Conversely, as illustrated by the raging debates about the role of Islam in the revolutionary uprisings in the Middle East and North Africa region in the early 2010s, religion and revolution can often come together, or even merge, in the claims they make upon people. Being a good revolutionary may in certain contexts become an element or expression for being, say, a good Muslim.

In this chapter we use the link between revolution and religion as a heuristic device for exploring the ways in which revolutionary transformations operate on, and at, the scale of the person. To be clear: our aim is not to chart out the complexities of the relationship between revolution and religion for their own sake. This is a theme that we shall be encountering again and again throughout this book, as in this chapter, and which we shall be treating most explicitly in chapter 6 as part of a broader anthropological argument about the cosmological variability of revolutions, as well as their cosmogonic qualities. In the present chapter, however, we are interested in the relationship between revolution and religion for what it tells us about the way revolutions constitute people. The rationale for this is simple. If religious phenomena are preeminently about the formation of particular kinds of "subjects," as some of the recent literature refers to people in this context (see also Laidlaw et al. 2018), then the complex and varied ways in which revolutions relate with religious practices in different ethnographic settings can tell us a great deal about how the formation of persons is also at stake for revolutions. The contested correlations between revolution and religious practices in particular settings, in other words, brings revolutions' claims to and on processes of personal transformation to the surface, making them ethnographically visible and analytically legible.

Locating our anthropological approach in relation to the broader literature on revolutions, we note that questions about the formation and transformation of "revolutionary subjectivity" have received close attention by political theorists and philosophers in particular, often in ways that resonate with revolutionary protagonists' own concerns over how people capable of carrying the torch of revolutionary struggle are to be formed. Louis Althusser's influential "structuralMarxist" analysis of ideology (2001), for example, had at its heart the question of how such institutions as family, school, and church make deeply ideological conceptions about what people are and how they ought to behave seem natural. For Althusser, this happens through processes of "interpellation"-the manners in which these institutions turn concrete individuals into ideologically freighted 
"subjects" by "hailing" them, as when one might turn, for example, in response to a policeman calling out, "hey, you there!," and in doing so take for granted one's own subjection to his state-sanctioned authority. Revolution, for Althusser, could only be successful if it replaced these subject-forming "Ideological State Apparatuses," as he called them, with radically new ones, capable of sustaining a truly proletarian class consciousness-a task with which, as Althusser laments for the Soviet case, Lenin was deeply concerned but did not live long enough to carry out (2001: 91-92).

In later chapters we shall encounter other ways in which philosophers of revolution have dealt with the question of "the subject." In more recent debates in the European radical Left, as we shall see, Alain Badiou has suggested that events, including revolutions above all (see also chapter 1 ), are able to constitute the very subjects who show "fidelity" toward them (Badiou 2001) — an idea that Badiou sources back, tellingly, to the narrative of St. Paul's conversion (2003; see also Robbins 2010). Rather than reviewing this whole body of literature, however, for the purposes of this chapter we shall limit ourselves to examining the thinker who has had the strongest influence on anthropologists' writings in this fieldnamely, Michel Foucault. Foucault's influence on anthropologists' thinking about how people are constituted in different ethnographic contexts-how particular political, economic, or other institutional practices and arrangements have different "subject effects," as the Foucauldian terminology has it-goes well beyond the study of revolution. Running in some ways parallel to Althusser's argument about ideological interpellation (see also Montag 1995), Foucault's basic concern with the constitution of subjects as a contingent historical process has been taken up eagerly by anthropology, melded with the discipline's long-standing interest in localized ideas of "personhood" and the practices in which they emerge. What is so interesting about Foucault's engagement with revolutionary subjectivity in particular, however, is that it marks a shift in his own thinking about how subjects are "effected." While in his "early" works the constitution of subjects is seen as primarily an effect of different arrangements of power (as seen in such classic studies as Madness and Civilization [1988c], on confinement in mental institutions, and Discipline and Punish [1995], on prisons and surveillance), in his "late" period subjects are constituted through ethical practices of self-care, which, in his famous lectures at the College de France at the turn of the 1980s, Foucault called "technologies of the self" (1988b).

That this idea of self-formation should resonate so strongly with revolutionary practices is no accident. For, as we shall see, this shift in Foucault's thinking coincided with his much-discussed sojourn in Iran, where he witnessed firsthand the revolution that brought Ayatollah Khomeini to power in 1979. The peculiar blend of the revolution's political aims with Shi'a forms of religious asceticism, which so fascinated Foucault, brings to the surface precisely the kinds of questions of 
revolutionary self-formation we focus on in this chapter. Starting with Foucault's account of them, therefore, allows us to place our anthropological approach to revolutionary personhood in the context of the broader questions of self-formation raised by Foucault's work. But it also provides an opportunity to explore ways in which the comparative perspective of anthropology can forge alternatives to Foucauldian analyses, which, as others have also remarked (cf. Boyer 2003; Stedman Jones 1996), sometimes tend to take the oxygen out of debate, albeit owing, no doubt, to the brilliance of Foucault's insights.

\section{FOUCAULT IN THE IRANIAN REVOLUTION}

Foucault's writings on the Iranian Revolution, and particularly those he wrote in 1978 in Tehran as a self-styled "philosophical correspondent" for the Italian daily Corriere della Sera, have been nothing if not controversial. Foucault's exuberant enthusiasm about the "political spirituality" of a revolutionary uprising that, as we saw in the previous chapter, conjoined leftist, anticolonial impulses with Shía spirituality and ritual in a manner that to him seemed entirely original, was met with suspicion in Europe and, as the revolutionary "Islamic Republic" soon descended into dark years of terror, with real opprobrium (see also Carrette 2000). A whole furor erupted at that time about whether Foucault, in his apparent endorsement of the events unfolding in Iran, had acted as an apologist for what turned out to be an abhorrently brutal machinery of power, with tendencies toward "archaic fascism," as one critic of Foucault put it at the time (Rodinson 1981: 233). More recently, in a highly charged critique of Foucault's Iran-inspired oeuvre, Janet Afary and Kevin Anderson (2005) have posed what they see as Foucault's relativist validation of Khomeini as an example of a broader failure by the European Left to subject the rise of Islamism to rigorous critique-an intellectual appeasement that, according to Afary and Anderson, opened the way for "postmodern" intellectuals' indulgent reactions to $9 / 11$ and its aftermath.

In a landmark study of Foucault's writings on Iran, framed as a response to Afary and Anderson's attack, Iranian sociologist Behrooz Ghamari-Tabrizi (2016) argues forcefully that these critiques not only get Foucault wrong but also misrepresent the Iranian Revolution (in which Ghamari-Tabrizi himself participated as a militant Marxist-Leninist student at the time). Foucault's enthusiasm for what was happening in Iran in the late 1970s, argues Ghamari-Tabrizi, was not born of a romantic fascination with premodern alternatives to Western liberal modernity, as Afary and Anderson suggest, nor was it part of an argument from or for moral relativism. Rather, in the momentous manner in which the Iranian Revolution put Shi'a conceptions and practices at the heart of the uprising against the Shah and his Western backers, Foucault saw an attempt to redefine the very conception of revolution and its transformative potentials. Seen against the background of the 
post-1968 disillusionment of the European Left with revolutionary politics, argues Ghamari-Tabrizi, Foucault's Iran-inspired writings sought above all to explore alternatives to linear, developmentalist conceptions of History (including the Marxist), which posits revolution as a teleological project "firmly rooted in a past orientation and a future projection" (Ghamari-Tabrizi 2016: 59). Instead, in Iran Foucault saw the possibility of revolution understood as "a moment when historical subjects refuse to subject themselves to History" (59). Foucault puts the point forcefully in his final piece on Iran, published in May 1979 in Le Monde, partly in response to commentators who ridiculed his support for a revolution aimed at establishing an Islamic state:

Uprisings belong to history, but in a certain way, they escape it. The movement through which a lone man, a group, a minority, or an entire people say, "I will no longer obey," and are willing to risk their lives in the face of a power that they believe to be unjust, seems to me to be irreducible. (Foucault, quoted in Ghamari-Tabrizi 2016: 70)

Central to Foucault's conception of the Iranian Revolution as a nonteleological, essentially irreducible phenomenon is the role he saw Shi' ism play within it, and it is in this connection that the question of personal transformation arises so importantly for him. The political spirituality that Foucault saw on the streets of Tehran involved infusing the political aim of overthrowing the Shah with the ascetic ethics of martyrdom and penitence that lie at the heart of Shi'ism. Indeed, among the most striking features of the Iranian revolution was its overtly Shi'ite symbolism and practice-public self-flagellation, demonstrations of men and women wearing black shirts and veils, displaying photos of dead "martyrs," and so on. While for many commentators this was all evidence of a frighteningly conservative traditionalism at the heart of Khomeini's movement, for Foucault they bespoke a more open horizon of revolutionary transformation. Crucially this opening was at base a matter of personal transformation-a concern Foucault saw at the heart of Shi'a rituals of penitence and martyrdom. His explanation of this point, given to the Iran correspondents of Libération in March 1979, merits long quotation:

In rising up, the Iranians said to themselves-and perhaps this is the soul of the uprising: "Of course, we have to change this regime and get rid of this man, we have to change the corrupt administration, we have to change the whole country, the political organization, the economic system, the foreign policy. But, above all, we have to change ourselves. Our way of being, our relationship with others, with things, with eternity, with God, etc., must be completely changed, and there will only be a true revolution if this radical change in our experience takes place." I believe that it is here that Islam played a role. It may be that one or other of its obligations, one or other of its codes exerted a certain fascination. But, above all, in relation to the way of life that was theirs, religion for them was like a promise and guarantee of finding something that would radically change their subjectivity. Shi'ism is precisely a form 
of Islam that, with its teaching and esoteric content, distinguished between what is mere external obedience to the code and what is the profound spiritual life; when I say they were looking to Islam for a change in their subjectivity, this is quite compatible with the fact that traditional Islamic practice was already there and already gave them their identity; in this way they had of living the Islamic religion as a revolutionary force, there was something other than the desire to obey the law more faithfully, there was the desire to renew their existence by going back to a spiritual experience that they thought they could find with Shi'ite Islam. (Foucault, quoted in GhamariTabrizi 2016: 65-66)

This ear-on-the-ground commentary on Iran, in its rudiments, is a statement of the essence of Foucault's "late" argument about "technologies of the self." Subjects are not only constituted by the arrangements of power that conduct their conduct (this being the core idea of "early" Foucault), but also through the "care" that they are able to direct at and for themselves in ways that have the potential to "radically change their subjectivity," as Foucault puts it in the above quote on Iran. Indeed, one of Ghamari-Tabrizi's central concerns is to show how Foucault's interest in the correlation of political and personal transformation in the Iranian Revolution marked the turning point in his broader thinking about subjectivity and power, setting in motion the analysis of the self and its care that he developed, famously, in relation to ancient Greek and early Christian forms of ascesis (Foucault 1986). For our purposes here, we focus more narrowly on what is in many ways an anthropological tenor in Foucault's writings on Iran, and what this may contribute to an anthropological understanding of revolutionary personhood.

To be sure, there is a basic confluence between Foucault's attempt to find in the Iranian Revolution an alternative to the scripted "progressivist" notions of revolution that he expected his European readers to take for granted, and our anthropological attempt in this book to multiply conceptions of revolution by attending to its different ethnographic manifestations. Indeed, his argument to an extent adopts the critical stance that is characteristic of anthropology. The contingency of the Iranian case is deployed as a vantage point from which to dislodge the certainties of "the age of revolutions," as he calls it, which for the past two centuries has constituted "a gigantic effort to acclimate uprisings within a rational and controllable history" (Foucault and Bernauer 1981: 5). Shi'ism is at the heart of this argument because it serves to relativize the standard image of revolution in two crucial ways, both of which have to do with the forms of personhood it cultivates.

The first relates to the association of the uprising with the public rituals of penitence with which Shi'ites commemorate the death of Hussain-the grandson of the prophet Muhammad who is central to Shi'a devotion-at the battle of Karbala. ${ }^{1}$ According to Foucault, the ethic of self-sacrificial martyrdom that these

1. The battle was fought in $680 \mathrm{CE}$ between the army of the second Ummayad Caliph Yazid I and a small army led by Hussain. In the Shía tradition Hussain is seen as a martyr who stood up against 
public reenactments of the trauma of Hussain's death at Karbala perform adds a deeper spiritual dimension to the overtly "political" aims of revolutionary violence (e.g., in the Iranian case, the deposition of the shah and takeover of the state machinery). While people's preparedness to die for the cause is necessary for the revolution to be effective, its expression as (re)enactment of Shi'a martyrdom turns this into an act of personal religious devotion (see also Ansari, forthcoming). The sacrifice, precisely, of the "self" takes to its very limit the religious injunction to "change ourselves," as Foucault had it, and renders it coterminous with the revolutionary struggle - a continuity of meaning that is encapsulated in all of its complexity in the Muslim notion of jihad (Heck 2004). Furthermore, secondly, the character of "spirituality" that Foucault finds in Shi'ism in particular allows him to posit the "irreducibility" of the revolution, as he sees it, as an essentially exploratory, open-ended act that defies the teleologies of History. Behind its adherence to religious codes and the identitarian politics that they furnish-though also, as we saw in the quote above, because of them-Shi' ism opens up a horizon of "existential renewal." And, once again, the correlation of the personal and the political that is achieved in the Shi'a conception of martyrdom renders the possibility of subjective change and the injunction to search for it a project of political exploration, too-a collective act of renewal that renders history "uncontrollable" and, in that irreducible sense for Foucault, revolutionary.

Yet there is also a basic sense in which Foucault's approach is significantly different from the anthropological tack our book develops, and this has to do with the strongly normative streak in his conception of the technologies of the self-a normativity that rubs off onto his conception of revolution, too. While, as Ghamari-Tabrizi argues against Foucault's critics, Foucault's account of what was happening on the streets of Tehran was certainly more thoughtful than just an endorsement of Khomeini and his politics, his effusiveness is nevertheless significant: for Foucault Iran provided an exemplar not just of what revolution "could" be, but of what it ought to be. Indeed, the desire to make an argument for a particular kind of revolution, in the context of what developed also into an argument for a particular kind of ethics in his subsequent work, is evident in the unabashedly motivated, even partial manner in which he treats the Shi'a dimension of the uprising he witnessed. While his philosophical point about the irreducibility of revolution to history is profound-and we shall return to this idea in later chapters-from an anthropological point of view, Foucault's appeal to Iran to make his point is problematic.

a tyrannical and unjust ruler. According to Hamid Dabashi $(1993,2011)$ the notion that injustice should be always fought against, as exemplified in the battle of Karbala, is at the heart of Shi'a Islam, so that Shi'ism is best understood as a religion of protest marked by inherently revolutionary tendencies. For an analysis of the role played by the battle of Karbala in contemporary Shi'a contexts, see Pinault 1999 and Deeb 2009. 
On the one hand, while, as we saw, Foucault points to the specificity of Shi' ism as a "form of Islam that ... distinguishe[s] between mere external obedience to the code and what is the profound spiritual life," he rather quickly presses his point about Iran to the service of a broader argument about the political spirituality of revolution. This glosses over a whole series of questions about the varying manifestations of political spirituality (if such they are) in different religious traditions (e.g., particular forms of Islam compared to each other, or to particular forms of Christianity) at different times and places and in different political circumstances. Considering the significance that Foucault's own genealogical method attaches to understanding practices as they are enacted in particular times and placesthe kind of attention to specificity that is amply evident in his genealogical presentation of ancient Greek and early Christian forms of ascesis in works that, as Ghamari-Tabrizi suggests, his experiences in Iran partly inspired-it is surprising that Shi'a concepts and practices of penitence and martyrdom should be treated in such a generic way. For example, what might the implications be of the differences, both ritual and theological, between, say, the Shi'ite rituals of penitence during the celebrations of Muharram and the early Christian tradition of exomologesis (which Foucault discusses in detail in subsequent writings-Foucault 1979), for the enactment of subjective transformation in different political circumstances? How, furthermore, might the distinction between "external obedience to the code" and a more inwardly transformative "spiritual life" be modulated by these differences, and what difference might this make for the potentials of political transformation in each case (see also Ghannam 2015)?

On the other hand, Foucault's desire to generalize from the Shi'a dimensions of the Iranian Revolution also tends to render his reading of the Iranian case itself rather selective. For example, alongside the emphasis on penitence and martyrdom, a more rounded analysis of the Shi'a dimensions of the Iranian Revolution would chart out the varied ways in which what Foucault calls the "obedience to the code" of religious dicta may have also played important roles. As anthropologist Roxanne Varzi (2006: 33-43) has shown, for instance, Khomeini's charismatic leadership, which allowed him to command such obedient devotion among his followers during and after the revolution, was constituted partly by the way he cultivated his status as an imam. In the Twelver tradition of Shi' ism that is the official religion of Iran, this term is reserved for the spiritual successors of the prophet Muhammed, who were assassinated one after the other by rival groups over the centuries, until $874 \mathrm{CE}$, when the Twelfth Imam went into occultation (ghayba), with a promise to return at the end of the world as the Mahdi (a redeemer who will bring justice and peace, as per Islamic eschatology). As Varzi shows, Khomeini's claim to having an unmediated connection to the divine was central to his role at the apex of the Islamic Republic after the revolution, and integral to the doctrine of Governance of the Jurist (velayat-e faqih), which he instituted as the prime 
principle of his theocratic government, as we also saw in the previous chapter. The image we are left with, then, is one that is rather more complex and contradictory than the one Foucault presented. Even as Shi'a esotericism may support the opening of subjective horizons Foucault celebrated, it also bolsters particular forms of leadership and political control that underpin the authoritarian character of the Islamic Republic Khomeini and his supporters instituted, which became so evident after Khomeini took power.

The enormous impulse that Foucault's late work on the self has given to anthropology at large since the 1990s - and not least to the anthropology of Islam (Asad 1993; Mahmood 2005; Hirschkind 2006) — can be understood partly as an attempt to add ethnographic depth and comparative rigor to his insights about the transformational potentials of the self. For example, stimulated by the Foucauldian agenda set for the anthropological study of Islam by Talal Asad in particular (1993, 2003), Saba Mahmood (2005) has offered a widely influential-and much debated (e.g., Marsden 2005; Schielke 2010; Elliot 2016) - account of the political potentials of women's piety movements in Cairo, seeing them as particular ways of configuring human agency and freedom in relation to God. While the study predates the Egyptian uprisings of 2011, it provides a penetrating analysis of the ethical underpinnings of radical mosque movements that formed part of the emergence and appeal of the Muslim Brotherhood. In particular, it shows how these movements sought to present an alternative not only to Western-style conceptions of a "liberal self" but also to some Sunni clerical discourses that framed the practice of Islam more in relation to national aspirations than as a matter of personal transformation. Alas, Mahmood, who died in 2018, was not able to trace the consequences of her analysis for an understanding of the revolutionary dynamics of Tahrir Square and its tumultuous political aftermath. We may note here, however, both resonances and contrasts between her ethically oriented argument and Amira Mittermaier's analysis (2014) of the relationship between the ethos of Tahrir Square and Sufi-inspired sociability of sharing in the khidma, discussed in chapter 1.

Perhaps the most systematic Foucauldian study of the constitution of revolutionary subjectivity, however, is provided in Oleg Kharchordin's magisterial account (1999) of the relationship between the collective and the individual in Soviet Russia. Framing his work as a counterpart to Foucault's archaeology of individuation in Western Europe, Kharkhordin unearths the genealogy of Bolshevik conceptions of the individual in the Russian Orthodox tradition, and particularly the public rituals of penitence that were much more central to its development than they were in Catholicism and the Reformation. ${ }^{2}$ Central to this

2. Caroline Humphrey offers an alternative account of the genealogical entwinement of religion and revolution in Russia based on a study (2014) of the excommunicated communities of Old Believers of Trans-Baikalia during the Soviet and post-Soviet periods. 
genealogy is the concept of oblichenie, translated as both "to accuse" and "to reveal the self." The concept goes back to the very beginning of the Russian Orthodox Church, and has its roots in exomologesis - the early Christian rites of public penance (the very rites that Foucault too, as we saw, connects back to in his account of Shi'a rites of martyrdom in Iran). Through the centuries, Kharkhordin shows, oblichenie denoted both practices through which the sins of the powerful and the heretics were exposed ("accusation") and rites of penitence through which a believer's own saintly self was revealed by rigorously rejecting sinful behavior ("self-revelation").

In the nineteenth century, however, at a time when its practice by the church had begun to wane, oblichenie occupied an increasingly central place in the discourse in the revolutionary movements that presaged the rise of Bolshevism, referring particularly to the revolutionaries' task of revealing the misdeeds and injustices of the Tsar and his government. By 1902, in What Is to Be Done?, Lenin himself adopts the term to describe the Bolsheviks' mass commitment to revealing injustices and other issues to be rectified by the revolution. Following the revolution of 1917 and the ensuing civil war, however, oblichenie begins to refer also to the acts of criticism and, importantly, self-criticism through which the faults of errant Party members and, later, ordinary citizens at large were exposed. In a way that bore striking resemblance to the workings of the ecclesiastical courts, Kharkhordin shows, the collective tribunals that were held not only by Party structures but also, as the 1920 s progressed, in all collective milieus of Soviet life (schools, offices, factories, etc.) turned most crucially on these acts of public selfexposure. And as the most chilling part of Kharkhordin's genealogy shows, by the 1930s oblichenie had become the central means through which the terror of Stalin's "purges" was conducted.

These modalities of public self-revelation are central to Kharkhordin's account of Soviet understandings of the "individual" (lichnost'). Just as, for Foucault, practices of penance were a prime arena of individuation in the history of Christianity, so the Bolsheviks' adaptation of such rites for revolutionary purposes contributed to the particular conceptions of the individual that developed in Soviet Russia. Kharkhordin makes the significance of this parallel clear:

The Russian Revolution may have effected a change similar to the Protestant Reformation, which also intensified an early Christian practice to reinvigorate the ailing religiosity. Luther made Augustine's solitary confession into the central practice of what became Protestant culture . . . . In doing so, he received credit for helping develop the individualism of Western culture. The Bolsheviks similarly radicalized those ecclesiastical practices that were available to them in their culture, based on Eastern Christianity and the centrality of public penance. Instead of using the aristocratic models of individualization copied from Western models of confessional practices and solitary self-reflection, they turned the Orthodox practice of oblichenie, nearly defunct in the official Russian Church, into the predominant mechanism 
of bearing witness to one's achievement of lay sainthood and "assurance of grace." The radical reformation of ecclesiastical practices in this case also yielded an individual, but of a specific kind. If the Western individual was born as a confessing animal, its Soviet counterpart came to be a penitent beast. (1999: 228)

This trajectory relates also to the particular inflection given in this context to the revolutionary conception of the New Soviet Man-the "superman" of our epigraph from Trotsky. First put forward as the ideal for revolutionary activists in Nikolai Chernyshevsky's bestselling novel of 1863, What Is to Be Done?, the idea that the revolution's success depended on changing "the very nature of man . . . to conform to the requirements of [the] new order" (Alt and Alt 1964: 23) was central to Lenin's own revolutionary manifesto of the same title, published in 1902 (2008). For Lenin this was above all a matter of cultivating among the workers a new kind of soznatelnost'-a word commonly translated as "consciousness," but which Kharkhordin argues is better translated as "Conscience", to reflect the ethical as well as spiritual dimensions of its usage (1999: 57-59). Fostering such a Conscience, not only among a select few New Men, but, on that model, among all Bolsheviks and ultimately all citizens, became a prime task of the revolution and the wholesale transformation of Russian society it sought to precipitate. The Ninth Party Conference of 1920, for example, proclaimed that the only legitimate grounds for differentiating between Party members would be "on the basis of the degree of their soznatelnost, dedication, endurance, political maturity, and readiness to sacrifice themselves" (cited in Kharkhordin 1999: 59-60) - the hallmarks, in other words, of the New Soviet Man. It was precisely the possession of these characteristics that, then, the public fora of Bolshevik oblichenie were designed to test-at first by revealing the deeds (revolutionary or otherwise) of the individual under scrutiny, following the pattern of the Orthodox rites, and then, with Stalin's rise to power, delving deeper and deeper into the hidden recesses of people's "selves" (sebia), passing judgment on their whole personality, and, at the height of the Great Terror of the late 1930s, rendering even their intentions potentially culpable (ibid., 180-81).

Tracing a line from religious rites of penitence not to "political spirituality" but to the horror of Stalin's purges, Kharkhordin's analysis demonstrates beautifully how the normative character of Foucault's approach to revolutionary transformation can indeed be sidestepped, deploying Foucault's core insights on the subjective effects of self-care to provide nuanced accounts of the ambiguities of real-life revolutionary situations. Still, there may also be something limiting about framing the question of revolutionary personhood in Foucauldian terms alone. The framework-indeed the language-that Foucault's body of work provides has become so dominant in the anthropology of political subjectivity in recent decades that it can end up being somewhat domineering, acting a little like a technology of the (anthropological) self in its own right. Productive as it can be, the core image of "individuals [effecting] by their own means or with the help of 
others a certain number of operations on their own bodies and souls, thoughts, conduct and way of being, so as to transform themselves in order to attain a certain state of happiness, purity, wisdom, perfection, or immortality" (Foucault 1988b: 18), as Foucault's famous definition would have it, can seem unduly narrow to anthropologists accustomed to thinking of the constitution of the person in terms of a much more varied set of social contexts-including, most classically, entirely mundane activities related to kinship (e.g., Carsten 1997), say, or exchange (Mauss 1990; Strathern 1988). Certainly, to develop a comparative framework for thinking about revolutionary personhood, one must be able also to think beyond the ascetic forms of spirituality that Foucault's genealogy traces back to Greece and early Christianity.

Our proposal in this regard is, if you like, to "demote" Foucault's framework, as but one possible realization of what we shall call the "anthropologies of revolution." Here we mean the term "anthropologies" not as a tag for the disciplinary approach this book seeks to promote, but rather, to help make that argument, drawing on the term's theological meaning: anthropology as the study of humans in relation to God and the providential universe of divine creation (e.g., see Cortez and Jensen 2017). For purposes of the study of revolutionary personhood, of course, this theological understanding of anthropology can only be metaphorical. Yet the analogy on which the metaphor relies is not loose and, in view of our foregoing comments on the relationship between revolution and religion, can also be revealing. Theological anthropology asks questions about how to conceive of the relationship between humans and a transcendent God who created them, as well as the world in which they live, including the demands that this relationship places on people's personal comportment "in God." In a move reminiscent of relevant debates in "political theology" (e.g., Scott and Cavanaugh 2008), we seek basically to adopt this set of questions by replacing "God" with "revolution." Whether they are understood as events, projects, or values and ideals, revolutions too can be conceived as transcendent (in whatever sense) in relation to the people they involve. Moreover, as we shall be showing more and more concertedly in chapters to come, they characteristically have a godlike capacity, if not to create a world ex nihilo, then certainly to change drastically the coordinates of the worlds that people inhabit-this being what, in the Conclusion, we shall call the "cosmogonic" character of revolution. But before we get to that, we are already well underway to seeing how revolutions make demands on people-again, like a divine entity might do-placing limits on and opening new prospects for their personal comportment as subjects. So, the different ways in which the relationship between revolutions and the people they involve is constituted and shaped, how this refigures ways in which people see themselves and their relations to other people as well as to the processes and institutions of the revolutionary project, and what forms of personal transformation this may precipitate in different 
contexts-these are the kinds of questions our focus on "revolutionary anthropologies" asks.

Foucauldian questions about technologies of the self, with their accompanying discussions about agency and freedom as well as piety and spirituality (Laidlaw 2014), certainly form part of such an "anthropological" framework. Foucault himself seems to indicate as much when, in the passage cited above, he imagines Iranians verbalizing their revolutionary fervor as a matter of completely changing "our way of being, our relationship with others, with things, with eternity, with God, etc." - that is as good a list of "anthropological" questions as any, albeit cast in the key of Shi'a self-care. Taking this broader approach, in fact, would allow us to include in the study of revolutionary personhood questions that arise also from the topics we have already broached up to this point in this book. Varying kinds of ritual, as mentioned already, both presuppose and precipitate different forms of personhood. For example, one could contrast the Shi'a asceticism that was Foucault's focus with the rituals of spirit possession Lan describes in his study of Zimbabwe, to explore how this contrast plays out in the constitution of revolutionary subjectivity in each case. In view of the long-standing social anthropological contention that people are constituted according to their position with different kinship formations and other local structures of social organization (e.g., Fortes 1983), one could similarly explore the consequences for the question of personhood of many of the issues discussed in chapter 2. For example, how does the universalizing image of the revolutionary "citizen" that revolutions often promote articulate with ideals of personhood that take form in more localized and variegated social structures, including, for instance, gendered values of duty, honor, or courage. Indeed, gender is particularly important in this context, and much empirical work in this field has called into question the androcentric - indeed patriarchalassumptions that undergird not only the discourse of revolutionary protagonists themselves but also that of its analysts (Davis 1983; Molyneux 1985; Tétreault 1994; West 2000; Babb 2001; Härkönen 2016; Wilson 2016). ${ }^{3}$ How, if you like, are images of the New Man modified and modulated in relation to these more localized ideals of humanity, and should that not also be New Woman? - questions that could also be examined in relation to conceptions of leadership and charisma that will be the topic of our next chapter.

Rather than go over this ground here, for the remainder of this chapter we shall use two examples to illustrate some of the questions that arise from the study of revolutionary personhood. Adopting their relationship to religious practices and concepts as a heuristic prism, as suggested above, our aim is to chart in each case

3. A more thorough discussion of this point is offered by Alice Wilson in her entry for the Cambridge Encyclopedia of Anthropology, from which we have sourced some of the references adduced here (Wilson 2019). 
the coordinates that give different revolutionary "anthropologies" their shape in each context. We begin with a study of the formation of personhood in the Chinese Communist Revolution, focusing on Maoist conceptions in particular as a prime point of reference for the very idea that revolutions turn crucially on their capacity to produce "new people."

\section{MAO'S MODELS OF THE NEW MAN}

Looked at from the middle distance, the role given to the cultivation of revolutionary subjects in Mao Zedong's revolutionary China is strikingly similar to what we saw in relation to Kharkhordin's discussion of the Bolshevik revolution in Russia. All the same ingredients are there: the idea of a New Man, the emphasis on altruism and self-sacrifice, a battery of techniques of personal surveillance and control involving public criticisms and denunciations, together with demands for selfcriticism and other acute forms of self-revelation. Indeed, as Chinese-American historian Yinghong Cheng (2009) shows in a detailed discussion of the development of these practices in China (on which our account here is mainly based), Mao and the Marxist-Leninist Party structure he founded in the 1920 s in many ways modeled China's path to revolution on Russia's, while also diverging from it critically and sometimes pushing it in more radical directions. When it comes to the systematic and psychologically violent ways in which revolutionary personhood was molded after Mao's ascent to power in 1949-forms of "thought reform" that are often described in the literature as Orwellian (cf. Quo 1988)—comparison between China and Soviet Russia bears out Martin Malia's contention that "each revolution learns from the experience of its predecessor, and so escalates . . e each time to a more intense level of radicalism" (2006: 5).

This may appear surprising in light of Kharkhordin's genealogical argument about the specifically Russian Orthodox background of Soviet conceptions and practices of revolutionary personhood, and the same could be said of the prominence given in China to the very idea of a "New Man," with its strongly Pauline sonorities. To be sure, the question of how revolutionary practices are able to travel as self-purported "universals" and take root in diverse sociocultural environments, and how to think about this anthropologically, is one to which we shall be returning repeatedly in later chapters. Here, however, we dig a little deeper into the Chinese case to reveal some of the distinctive features of the Maoist approach to revolutionary transformations of the person, founded on the notion that a revolutionary reconstruction of Chinese society must involve, as Mao put it as early as 1917, "reforming philosophy, reforming ethics, and fundamentally changing people's thought" (cited in Cheng 2009: 52). In particular, we focus on two distinguishing features. First, the question of "permanent revolution" in Maoist China, which, according to Cheng, involved also a relentless intensification of techniques 
of "thought control." Second, the emphasis placed throughout this process on the emulation of exemplary figures who personified the (in some ways shifting) ideals of the New Man. Recalling Kharkhordin's analysis of the Russian Orthodox roots of Soviet practices of self-revelation, our emphasis here will be on certain underlying Confucian dimensions of these forms of revolutionary action in Mao's China.

Mao's conception of the need for the revolution to be pursued as a permanently ongoing project of transformation has been much discussed by historians and political scientists (e.g., Schram 1971; Starr 2015), not least in comparison to Trotsky's earlier writings on prospects for a "permanent revolution" (e.g., Dunayevskaya 2003: 128-87), with which Mao himself compared his own (Schram 1963). A point often made is that the particular socioeconomic circumstances the Chinese Revolution had to confront, and particularly the predominantly agrarian character of the country's vast population, made Mao's doctrine of permanent revolution historically necessary. As Cheng also reiterates, for Mao's revolutionary program to be effective it had to take the shape of successive waves of ever-deepening and drastic sociopolitical transformation: from the initial uprising and ensuing civil war, through the sweeping social reforms of the 1950s, to the disastrous Great Leap Forward of 1958 after China's break with the Soviet Union, and then the violent human iconoclasm of the Cultural Revolution of the late 1960 s and 1970s. What makes Cheng's account relevant to our purposes here, however, is that he tells this story also as one of ever more penetrating attempts by the revolutionary process to reformat individuals, molding them into "new people" (xin min), in the idealized image of Mao himself as well as other selected models of revolutionary citizens.

In addition to the Soviet influences, Mao's program of thought reform had roots in his early involvement in the New Culture Movement of the 1910s. This comprised an urban intelligentsia who argued that for China to overcome the humiliation of defeat in wars with European powers as well as Japan, the population would have to overcome the docility of Confucian ethics and forge a "spiritual revolution," led by youth who could break the shackles of tradition and embrace the modern spirit of self-realization (with Friedrich Nietzsche's writings on the "superman" providing much of the inspiration). Combining the heroic tone of these influences with an idiosyncratic cosmology based on the notion of a "cosmic truth," the young Mao divided people into three categories-saints, sages, and the unwashed-according to how close they were to grasping this truth. Saints and sages were tasked with the education and enlightenment of the unwashed, creating the conditions for a new society to emerge. In 1918 Mao cofounded the New People's Study Society, in which a group of young intellectuals subjected themselves to a strict regime of study and Spartan physical hardship, with the aim of sharing the fruits of the collective program of enlightenment with uneducated peasants and workers through intensive educational campaigns. As the 1920 s 
progressed, Mao injected into these essentially ascetic structures a militantly Marxist-Leninist political content, and in the context of the newly founded Communist Party began to experiment with methods for bringing the program of thought reform to the masses.

The central planks of this momentous program of personal reform were put in place during the revolutionary struggle of the 1930s and 1940s, when Mao and his forces were based in Yan'an, a mountainous and isolated province of northwestern China. With a view to consolidating Mao's power and turning into effective revolutionaries the plethora of young recruits who poured into Yan'an to take part in the revolutionary campaign, the Yan'an encampments were systematically organized as "closed communities of discourse" (Cheng 2009: 60). The ideological doctrines of "Mao Zedong's thought," as Mao's adaptations of Marxism were branded, formed the curriculum of theoretical and practical instruction with which cadres-in-the-making were bombarded on a daily basis. It was in this context that one of the most pronounced-and in some important ways distinctive-features of Maoist "thought reform" was systematized; namely, its abiding emphasis on the emulation of model individuals who embodied the values of the revolution. Casting himself as "teacher" (rather than, say, leader) in a way that echoed the time-honored Confucian structure of moral guidance, Mao gave many of his most studied teachings the form of fable-like morality tales in which a central character - a worker, a soldier, a farmer, a cadre-acted out the virtues of the steadfast revolutionary. From Yan'an onward, through the successive waves of postrevolutionary convulsion that culminated in the Cultural Revolution, these tales became the centerpiece of the population's moral-cum-political education, with schoolchildren, workers, and soldiers, as well as Party cadres, learning to recite them by rote in morning assemblies that, as Cheng has it, resembled "a religious community's morning prayer" (63).

There is, of course, nothing exceptional about Mao's use of model individuals to bolster the appeal of his revolutionary project. In one way or other all political projects have their heroes, and Mao's technique of consecrating ordinary individuals as revolutionary exemplars was itself borrowed from the USSR, where tales of model workers, students, soldiers, scientists, mothers, and so on were standard fare for the masses' ideological formation as early as the 1920s (Cheng 2009: 33-37; Kotkin 1997; cf. Boym 1995). Nevertheless, as Cheng argues, in the Chinese context the appeal to model individuals as objects of moral emulation has deep roots in Confucianism, lending Mao's political project an unmistakably moral dimension in the eyes of a population long acquainted with Confucian ethical practice. Imitation, for Confucius, was a prime mode through which ordinary people could learn from their rulers, so it was the latter's duty to conduct themselves virtuously so that "the people are aroused to virtue" (Confucius, cited in Cheng 2009: 49; see also Hershock and Ames 2006). Indeed, to the extent that Confucianism runs together politics, government, and ethics as aspects of a single project of virtuous 
conduct (Yan 2016), Mao's manner of pursuing his revolutionary path to communism had an unmistakably Confucian hue to it-this being a paradox, of course, since the content of Confucianism had from the start been set up as an enemy of the revolution.

In an article focused mainly on Buddhist-informed ethical practices in Mongolia, Caroline Humphrey (1997) elaborates anthropologically a distinction between code-based ethical frameworks, in which subjects follow rules, and self-cultivating ethical practices based on the imitation of moral "exemplars"-individuals who are deemed to be morally exalted in one way or other, and therefore worthy of emulation (see also Needham 1992; Robbins 2018). The model individuals of Maoism, Humphrey acknowledges, can be understood as exemplars in this sense. However, their continuity with Confucian (or, in Chinese Inner Mongolia, Buddhist) ethical practices also invites unfavorable assessments on the part of the very people they are meant to inspire. For Humphrey, a compelling characteristic of exemplars is their inherent tendency toward richness and complexity, as subjects are called upon to reflect on the depth of varied exemplars' flesh-and-blood biographies, and actively consider which aspects of which exemplars (which may be potentially conflicting) to follow and cultivate for themselves. When Mao's government machinery "attempted to hijack exemplary precedents to their own ends" (Humphrey 1997: 25), seeking to "blot out all previous models [and] take over the moral landscape" (40), ordinary Mongols saw through it. "[E]veryone resented the brainless simplicity of these models," and, by the 2000 s when Humphrey was writing, "Mao's models have more or less zero currency" (41) (see also Liu 2002; Steinmüller 2011). If one can say that, in a deliberately unacknowledged way, Maoism treated Confucian (model-based) ethics as its model, what it produced was mainly bad imitations.

Still, as Cheng argues, there is more to Maoism's Confucian roots, particularly when one considers also its emphasis on self-reform, subjecting people to ever more forceful forms of collective criticism and self-criticism. Liu Shaoqi, Mao's influential deputy, explained the premise of this practice in his popular pamphlet How to Be a Good Communist, written during the Yanan period. After discussing the many ways in which self-avowed "communists" fall short of the ideal, Liu concludes:

Therefore people should realize the necessity of self-reform and see themselves as reformable. They should not assume themselves as unchangeable, perfect, saintlike, and thus needing no more reform. This is not meant to insult them but to recognise the inevitability of the progress of nature and society. Otherwise people could not achieve progress. (Liu Shaoqi, cited in Cheng 2009: 57)

As Cheng points out, it is significant that, to illustrate that even the most virtuous of men are subject to self-reform, Liu adduces the examples of Confucius and Mencius as models of purposeful and constant self-cultivation. Indeed, the notion 
that human beings are endlessly malleable and perfectible is a feature that distinguishes the Confucian tradition from the classical liberal conviction that humans are inherently both good and bad (cf. Cheng 2009: 59), or, as we might add, the Christian conception of sin that underlies the penitential traditions with which Foucault and Kharkhordin connect revolutionary self-revelation in Iran and the USSR respectively. And it is just this idea of self-reform as a permanent pursuit that underlies the regime of thought reform in Mao's China. Cheng illustrates:

Wang Yangming, a prominent neo-Confucian of the Song dynasty, was an example of . . . self-perfection. Before he died, he felt that, after a lifelong struggle against all undesirable thoughts, his mind and soul were so pure that, "There is nothing left in my mind but a holy emptiness." Many centuries later, in the Yan'an Rectification, Xie Juezai, a senior communist leader with a sound Confucian education, recounted this story in association with his experience of constant self-reform.

(Cheng 2009: 50)

Of course, "holy emptiness" is only one way of describing the effects of thought reform in China, which reached unprecedented heights of physical and psychological violence in the campaigns of the Cultural Revolution. While Cheng does not make this argument himself, it may be plausible to go as far as linking this violence to the basic notion of human malleability that he traces back to Confucianism. To the extent that techniques of thought reform were premised on the idea that "moral improvement has no fixed limit" (Cheng 2009: 59), aspects of an individual's character or thought that remained unamenable to reform were not just erroneous but, in a sense, abominable, and therefore the legitimate target of ever more aggressive methods of psychological eradication.

Going a step further, seen from the vantage of revolutionary "anthropology" we outlined earlier, the significance of this kind of malleable personhood in Maoist China illustrates also how basic understandings about the nature of the person can help to shape the way that revolution itself is conceived. As already mentioned, the concept of a "permanent revolution"-revolution as an ineluctable process of ever-shifting coordinates and ever-deepening transformative effects, pressing its own "progress" forward in new ways, under changing historical circumstanceswas central not just to Mao's thinking, but also to the course of history in Maoist China and its devastating trajectory of death and suffering. To be sure, as the vast literature on the topic shows (e.g., Starr 2015), Mao's theory of permanent revolution had a lot to do with the particular historical circumstances of the Chinese Revolution. Interestingly also, in relation to the argument about the subterranean links between Maoism and Confucianism, it has been asserted that Mao's concept of revolution in permanent flux was presaged by his early flirtations with Daoism and its cosmology of becoming (Schram 1971: 224-25). However, if, as Cheng's account shows, the transformation of people was a prime arena in which revolutionary transformation itself was registered, then one could also suggest that the 
permanence of Mao's revolution was, at least in part, a function of the permanence of the project of human perfectibility that it set in motion (see also Liu 2009: 185; Smith 2017). If revolution, as a political form, is about releasing the full potentials of human malleability, and that malleability has "no fixed limit," then the revolution also must be imagined as having no fixed limit either. A revolutionary anthropology, then, that posits transformation as a permanent state.

To illustrate further the subtlety as well as the complexity that a focus on revolutionary anthropologies can bring to the study of personhood in revolution, we now turn to a second case study, which draws on Holbraad's own research in Cuba (2004, 2012, 2014, 2017a, 2017b, as well as ethnographic material collected more recently). As we shall see, in many ways the anthropology promoted by Fidel Castro, Ernesto "Che" Guevara, and their fellow combatants after their rise to power in 1959 is a variation on the state-socialist conceptions developed in the Soviet Union and China, based on ideas about the concerted production of a New Man and his revolutionary potentials. However, focusing on the ideal of self-sacrifice that, much as in the USSR and China, lay in the heart of these conceptions, we go on to broaden the scope of the argument ethnographically, to consider how practitioners of Afro-Cuban religions that are active in Cuba today relate to these conceptions. Based on a different set of ideas about the significance of sacrifice - in this case animal sacrifice - in processes of self-transformation, participants in these popular religious practices also, at times, have seen themselves as contributors to the project of revolution in Cuba. The case, we argue, illustrates how a focus on the constitution of the person can take the analysis of revolutionary transformation beyond the rather hackneyed study of the divergence between ideology on the one hand and practice on the other, and reveal the nuanced and complex imbrications between the two (see also Yurchak 2006).

\section{TWO ANTHROPOLOGIES OF REVOLUTION IN CUBA}

From the first years of its inception, the Cuban Revolution has presented itself as a radical attempt to refigure the relationship between individual persons and the putatively transcendent state structures that govern them. In that sense, and as with other revolutionary processes we have discussed already in this chapter, the project of revolution in Cuba has been an "anthropological" one, too. In his emblematic text Socialism and Man in Cuba (in Guevara and Castro 2009), for example, Guevara addresses the "common argument from the mouths of capitalist spokesmen ... that socialism, or the period of building socialism into which we [in Cuba] have entered, is characterised by the abolition of the individual for the sake of the state" (7). To the contrary, Guevara argues polemically, the "fundamental task" of the revolution is to "build communism, [for which it is necessary] to build the new man (el hombre nuevo)" (13), who must "strive every day so that 
[his] love for living humanity is transformed into actual deeds, into acts that serve as example, as a moving force" (25). Far from being "abolished," for Guevara the individual in revolutionary Cuba is "freer" (26), fashioned into a subject who not only embodies the ethos of the revolution but enacts the very condition that the socialist state is charged with bringing about-an early example of political "prefiguration," as more recent debates on societal transformation would have it (Juris 2008; Krøijer 2015; Briceño 2018).

It is important to note here that while Guevara's notion of the New Man is but a version of the kinds of ideas we have already seen from previous state-socialist contexts, there are also aspects of his proposal that are distinctive, in ways that are relevant to our argument about revolutionary anthropology. For Guevara, as well as for Castro himself in those early years, before Guevara's death in 1967, the Cuban Revolution presented an alternative to Marxist "scholasticism," and particularly theories of "pure transition," according to which communism is supposed to result from objective conditions emanating from the class dynamics of late capitalism and, following revolution, the dictatorship of the proletariat (Guevara and Castro 2009: 16-19). On the contrary, argued Guevara, Cuba represented the possibility of speeding up this transition by supplementing the objective conditions for socialism-only partially met in the historical contingencies of revolutionary Cuba-with an irreducibly subjective component, namely forging the New Man. A matter of inculcating new forms of consciousness (conciencia) through intensive and all-embracing changes in political mobilization, labor arrangements, the arts and, above all, education, this focus on subjectivity (over and above objective conditions) was a crucial aspect of the Guevarist ambition for the "simultaneous creation of socialism and communism" (Bengelsdorf 1994: 91; cf. Badiou 2009: 25).

The "sped up" image of revolutionary transformation has interesting implications for the question of revolutionary anthropologies, and particularly the Cuban Revolution's project of reconfiguring the relationship between the (revolutionary) state and the (equally revolutionary) person. What is most deeply at stake in the Guevarist program of political-cum-subjective change, then, is not just a clash between two ways of organizing the relationship between a state and a people (liberal, say, versus totalitarian), but rather two alternative ontological positions on what might count as "state" and "people" in the first place. Where liberal assumptions premise the two sides of this political equation as (to a degree) mutually independent variables - sovereigns and subjects who retain their respective scopes for autonomy, with different degrees of relativity-Guevara seeks to articulate revolutionary politics in Cuba as a concerted attempt to render them mutually dependent: a "society in formation," as he writes, "that will permit a complete identification between the government and the community in its entirety" (Guevara and Castro 2009: 16, emphasis added). Expressed in the quasi-theological terms 
of "anthropologies," the revolutionary project in Cuba in those early years was one of mitigating the sense of transcendence that is typically taken to be an inherent characteristic of state structures, and rather orchestrate into existence a situation where the person and the state are effectively one and the same thing. A statesocialist revolution in which (new) people's individual deeds serve as a "moving force," and, in turn, a new man who in his (and the macho masculinism of the terminology is noteworthy!) constitution enacts the goals of the revolution.

Elsewhere, Holbraad (2014) has explored how this ideological notion of revolution as a fusion of state and person has remained practically operative in Cuba after the initial idealism of Guevara subsided into the realities and compromises of later periods of the revolutionary process on the island, including the so-called Special Period of the post-Soviet years of the 1990s and 200os. While, much as Humphrey describes for Inner Mongolia, Guevara's exalted notion of the New Man has for decades been considered hopelessly idealistic and outdated, one of its major premises has in a way persisted-its central commitment to self-sacrifice. During his fieldwork in Havana since the late 1990s, and even today, Holbraad found that at a discursive level ordinary people may take a range of stances toward what official discourse still calls "the revolutionary process" (el proceso revolucionario), including daily litanies of complaint about its many failings. Tellingly, however, in situations where their commitment to the revolution was challenged in one way or other, many of those same people would revert indignantly to an embattled language of self-sacrificial violence, affirming their own continued preparedness to fight for a political project they still saw, with self-conscious heroism, as "theirs" (see also Rosendhal 1997; Weinreb 2009; Gold 2015).

Holbraad's argument (2014) was that insofar as the association of revolutionary commitment with self-sacrificial violence runs deep even in contemporary Cuba, it continues to underwrite a conception of revolution as a fusion of state and person. As the ultimate expression and most basic premise of the ascetic ethos of the New Man, the commitment to self-sacrifice gives subjects a particular form, making them coterminous with the revolution which in turn is understood, as Castro put it in a famous speech in 1961, to contain "everything within" it (Castro, from García Luis 2008: 116-17; cf. Arendt [1965] 2006: 11-58; Kwon 2013; Atran 2016). Or, as Guevara himself proclaimed in 1965, two years before his own iconically self-sacrificial death, "there is no life outside the Revolution" (Guevara, cited in Pérez Jr. 2005: 349). In a way that may run as deep as biblical debates about Abraham and Isaac (Putnam 2008; cf. Miller 2014), then, the basic revolutionary demand for self-sacrifice configures a revolutionary "anthropology" that is just as powerful. Namely, one that orchestrates a political universe in which state structures and the people they co-opt stand not in a relationship of transcendence but rather one of mutual constitution, where state and subject may be said, following Lévy-Bruhl (1926; cf. Sahlins 2013; Goldman 2019), to "participate” in each other. 
This mention of Lévy-Bruhl, whose notion of participation was put forward as a feature of what he took to be the "mystical" premises of "primitive mentalities," suggests that our treatment of revolutionary anthropologies can be pushed further, to include also constituents whose involvement in the Cuban Revolution diverges from the Abrahamic logic of self-sacrifice promoted by the revolutionary authorities themselves. We have in mind here the practitioners of Afro-Cuban religious traditions, which were brought to Cuba from Africa during the slave trade, and which were severely restricted by the revolutionary authorities after 1959, only to resurface with vigor from the 1990 s onward, when government restrictions were relaxed in the difficult years of the Special Period (Holbraad 2004). To be sure, practitioners of Afro-Cuban religions in recent years have been just as liable as anyone else in Cuba to complain about the government and express their disappointment in a revolution that in its initial phases did so much to improve the lives of the working class and non-White segment of the population, among which these practices have traditionally been most popular (Ayorinde 2004). ${ }^{4}$ As with other ordinary people in this period, however, Holbraad found that in other contexts, and particularly when challenged or provoked, many of them would profess their loyalty to the revolutionary project, on occasion revealing that current of underlying violence which gives form to the self-sacrificial logic of revolution. For example, in the article making this argument about violence and the machismo of self-sacrifice, Holbraad recounts an occasion when a middle-aged man expelled from his home a drunken visitor who had mocked the images of Fidel Castro, Che Guevara, and Camilo Cienfuegos hung on the living-room walls, lurching at his visitor with a machete and shouting in paroxysm, "Get the fuck out! In this house we are revolutionaries, fuuuuck!" (Holbraad 2014: 368). What Holbraad did not mention in the context of that discussion, however, is that both men were longstanding initiates of Ifá, a prestigious, male-only Afro-Cuban tradition of divination. The machete that the host was able to dig out of his wardrobe for the attack was kept there (also) for ritual purposes, in fact, related to the animal sacrifices that are a central feature of Afro-Cuban religious practice.

One might conclude from this kind of ethnography that practitioners of AfroCuban religions are as thoroughly subject to the violent logic of revolutionary selfsacrifice as anyone else in Cuba, and that would be correct. However, for purposes of our present argument about revolutionary anthropologies, it is interesting to note also an altogether different framework of ideas and assumptions these practitioners are able to bring to bear on the political circumstances of the revolution. This springs from a more general logic of action that underpins all Afro-Cuban

4. For a study dedicated to understanding the dynamics of disappointment in a postrevolutionary society, based on ethnography in Serbia following the overthrow of Milosevic in 20oo, see Greenberg 2014. 
religious practice; namely, that the events that make up people's lives are always and in principle under the influence of divinities and other spiritual forces whose actions and dispositions influence the course of worldly events. As Holbraad $(2012,2019)$ explains with reference to the divinatory tradition of Ifá in particular, this subjection of life to divine forces follows a "mythopractical" logic, according to which all worldly affairs are traced back to their mythical origins. These are accounts or "stories" (historias) of their "birth" under the reigning influence of particular creator divinities, who are themselves expressions of an all-pervasive principle of creation and transformation, called aché. Managing one's affairs in this world, then, involves developing and regulating one's relationships with these divinities and forces through ritual actions. Animal sacrifice is particularly salient in this respect, "feeding" the divine entities with blood and other ritual substances to enhance their force and efficacy, that is, their aché.

These practices are appealing to practitioners since they allow them to influence personal affairs, and initiation into an array of different Afro-Cuba traditions is as popular in Cuba today as it ever was, allowing initiates to wield these powers for their own good and that of their clients and ritual protégés. However, broader social circumstances, including political affairs, are also understood to be subject to these divine forces. This is the case, for example, with the so-called letra del año-an annual divination that initiates of Ifá perform collectively at the beginning of every year, laying out the overall fortunes of practitioners for the year (Watson 2010: 160-211). Increasingly in recent years, this has included perceptibly political dimensions, with diviners pronouncing, albeit in the cryptic terms characteristic of this form of divination, on matters of national economy, prospects for migration, or the fortunes of particular political personalities (Routon 2009). Indeed, the manner in which practitioners subject Cuban politics to the mythopractical logic of their ritual practices was brought home to Holbraad in a conversation in 2002 with a prominent initiate of Ifá, who was expressing his indignation at the government's periodical attempts to co-opt the religions in more official structures. In the macho tonalities that are often characteristic of Ifá practitioners' discourse, he explained:

What they don't say is that were it not for us [the initiates of Ifá] this thing would have fallen long ago. We've got the Yankees to the North and everyone is against us. How many attempts have they not made against him [Fidel Castro]? But we feed this land (esta tierra), we give it the power it needs to resist, after all these years and all that we have gone through. Animals, animals, and more animals, for every initiation, every ritual. That's our work, the work we do for this.

"This" or "this thing," as Holbraad has discussed elsewhere (2017a), is a way Cuban people have in ordinary discourse of referring diffusely to the political circumstance that the "project of revolution" of official discourse had created. What we have here, then, is an altogether different framework for understanding the 
anthropology of the Cuban Revolution-one that turns the relationship between the state-driven project of revolution and its putative "subjects" (in this case the initiates of Ifá) on its head. Rather than the revolution co-opting and reformatting people through the demand of self-sacrifice, here we have people (initiates) sustaining the revolution by injecting it with the powers animal sacrifices provide. In this way revolution is itself co-opted by the power of the divinities, becoming a worldly expression of an all-encompassing logic of mythical-cum-divine origination. Initiates, who in the Levy-Bruhlian sense "participate" in (i.e., become a constitutive element of) this process of mythopractical transformation, effectively become the guarantors of the revolutionary process and its development against all historical odds. If, according to the official, Abrahamic-style revolutionary anthropology, the revolution "contains" people by rendering them ontologically coterminous with its own process through the ascetic demand of self-sacrifice, here we have an inversion. The revolution itself is "contained" by the sustaining life force of aché, which the initiates are able to wield and underwrite through the ritual actions of animal sacrifice.

\section{CONCLUSION}

The Cuban case illustrates our most basic point in this chapter-one that is obvious to any anthropologist-namely, that understanding how revolutions come to constitute persons, and how persons come to shape them in turn, must involve also studying local ideas and practices of personhood. In each of our examplesIran, Russia, China, and Cuba - the political project of transforming people into revolutionary subjects has been in one way or other aligned with local ideas about what people are, how they are constituted, and how they relate to others, including transcendent powers and divine entities. Indeed, questions about the shape such alignments might take are as live for the people involved in them as they are for the anthropologists who study them. For example, we have seen that in both Russia and China the revolutionary impulse was very much against the ecclesiastical and Confucian "traditions," which the project of creating a New Man was meant explicitly to eclipse. Nevertheless, as we saw, deep structural elements associated with these traditions were transposed into the revolutionary project itself, while also being significantly transformed by it. In Iran, at the other end of the spectrum, we have a revolutionary movement that draws much of its strength from local religious conceptions and practices, giving them a constitutive-indeed exaltedrole in the development of the revolutionary project. Far from seeking to replace Shi'ism, the Iranian Revolution becomes its prime avatar. Hence, for participants in the revolution, and subsequently for the subjects of the Islamic Republic it instituted, being a good Muslim and being a good revolutionary subject become demands that are inextricably linked, making the alignment of the two a prime 
reference point for ordinary people as much as for the state authorities charged with policing their comportment. And finally, contemporary Cuba provides an intermediary example, between the two extremes of mutual exclusion on the one hand and mutual constitution on the other. After years of Soviet- and China-like persecution (which was never nearly as violent in Cuba, however), since the $1990 \mathrm{os}$ Afro-Cuban conceptions and practices began to flourish within the country's everrevolutionary environment. In doing so, as we saw, they have been able to provide an alternative framework for understanding the relationship between revolution and person-one that, in its own terms, can be said to encompass the "anthropological" alignments that the revolution itself prescribes.

Rather than further proliferate the examples of revolutionary anthropologies, we end this chapter by placing our analysis of revolutionary personhoodindeed of "revolutionary anthropologies" - in the context of developments in the anthropology of personhood more broadly. In particular, our central question about how revolutionary conceptions of the New Man relate with diverse local ideas and practices of personhood resonates with a central theoretical question in the anthropology of personhood more broadly; namely, how far the conception of the person as an "individual," upon which much social theory is based, is useful for charting this ethnographic diversity. Revolutions the world over, as we have seen, have had to align a basically Eurocentric (not to mention Pauline and thus emblematically Judeo-Christian) idea of the person-the New Man and all of the assumptions associated with it-with local conceptions, often grounded in divergent religious and ritual traditions. Similarly, anthropologists must deal with the divergence between basic Eurocentric assumptions about individuality, autonomy, agency, and so on (many of them enshrined in the liberal tradition of the French Revolution, and carried through also to revolutionary conceptions of the New Man), and alternative conceptions that in many ethnographic contexts cut against these assumptions, rendering them quite unsuitable for anthropological description and analysis.

In anthropology at large, the limitations of models of personhood based on the idea of the individual have motivated a radical critique of "humanist" assumptions in anthropological analysis, giving rise to what is often referred to as a "post-humanist" stance (cf. Laidlaw et al. 2018). The tendency, broadly, has been to move away from ideas about individual freedom, agency, and autonomy as distinctly human characteristics, and toward more "processual" approaches that emphasize the relational constitution of persons and efface principled distinctions between humans and nonhumans (e.g., Braidotti 2013). Human beings, according to this view, are better understood not as entities in their own right but rather as emergent effects of complex and ethnographically contingent relational processes-be they, for example, shifting configurations of power and knowledge, as in early Foucault (1995), networks of human and nonhuman "actants," as Bruno 
Latour has suggested from the perspective of Science and Technology Studies (1993), or "dividuals" distributed across each other through relationships of kinship and exchange, as Marilyn Strathern has argued on the basis of Melanesian ethnography (1988).

As Humphrey has suggested in an influential article, tellingly titled "Reassembling Individual Subjects" (2008), however, these attempts to radically downplay individuality as a starting point for understanding personhood also come at a cost. Dissolving the individual in this way, she argues, tends to inhibit anthropologists' interest in people not just as "persons" but also as particular personalities. That is to say, alongside our interest in the varying processes through which the category of the person is constituted locally, as anthropologists we are also interested in the "singularity, or the originality of . . . particular person[s] as . . actor [s] in a given cultural situation and specific historical circumstances" (2008: 358). What is called for, therefore, are analytical frameworks that allow us to understand how "a singular human being might put him or herself together as a distinctive subject by adding to, or subtracting from, the possibilities given by culture as it has been up to that point" (358). Inspired partly by Badiou's theory of the event (2001, 2009), Humphrey develops such a framework by positing "decision-events" as moments at which people constitute themselves as individuals by "'plumping for' a specific way of being a person, if only temporarily, and by prioritizing, the keeping at hand of divergent multiplicities in an emotionally cogent, internally shuffle-able array of possibilities" (Humphrey 2008: 363, emphasis omitted).

It is telling that many of Humphrey's examples of this constitution of persons as individuals in the moment of decision are taken from contexts of revolutionary action, illustrating her model of decision-events, for example, with reference to the political trajectory of Bayar, a young activist who sought to instigate revolution in the Urad West Banner of Inner Mongolia in the 1920s (362-63). Going beyond her specific model of individuality, however, Humphrey's argument is significant here for the way in which it sets up the overall challenge an anthropology of revolutionary personhood must confront. We have seen throughout this chapter the many ways in which people's singularity as historically placed individuals with the capacity to act-and not least to change themselves, often in incredibly potent ways-is often at issue in revolutionary contexts. The very idea of a New Man is but an incarnation of this idea, but so is the broader demand for personal transformation and self-discipline that revolutions characteristically invoke and, to a degree (often a radical degree), enact. Revolutions, one might say, are rarely "post-human" in character-indeed, most often they are in one way or other carriers of the very forms of humanism much contemporary anthropological (and broader cultural and social) theory is pitted against. The challenge for a comparative anthropology of revolutionary personhood, then, is how to take this into account without sidelining the myriad ways in which local cultural and social inflections of revolution 
put these forms of "humanism" under pressure, often in a decidedly post-human direction, as we saw with reference to Cuba, for instance. For the anthropology of revolution, we might say, there is no choosing between "humanism" and "posthumanism" as alternative theoretical options. Rather, the relationship between the two becomes an ethnographic conundrum in its own right, amenable to a manifold of expressions in different historical, social, cultural, and indeed religious and ritual settings. 